\title{
River logjams cause frequent large-scale forest die-off events in southwestern Amazonia
}

\author{
Umberto Lombardo \\ CaSEs Complexity and Socio-Ecological Dynamics Research Group, Universitat Pompeu Fabra, \\ Barcelona, Spain \\ Correspondence to: Umberto Lombardo (umberto.lombardo@upf.edu) \\ Received: 28 February 2017 - Discussion started: 24 March 2017 \\ Accepted: 9 June 2017 - Published: 11 July 2017
}

\begin{abstract}
This paper investigates the dynamics of logjam-induced floods and alluvial deposition in the Bolivian Amazon and the effects these have on forest disturbance and recovery cycles. It expands on previous work by Gullison et al. (1996) who reported a case of catastrophic floods triggered by logjams in the Chimane Forest in the Bolivian Amazon. No further studies have followed up on this observation and no research has been published on the effects of large wood in tropical lowland rivers. The study is based on the analysis of a time series of Landsat imagery (1984-2016) and field evidence. Results show that logjam-induced floods are a major driver of forest disturbance along the Andean piedmont in the Bolivian Amazon. New logjams form on an almost yearly basis, always further upriver, until an avulsion takes place. Logjam-induced floods are characterized here by the sudden deposition of a thick sand layer and the death of forest in a V-shaped area. The Bolivian Amazon offers a unique opportunity for further research on how large wood affects river behavior in lowland tropical settings and how large and frequent forest disturbance events resulting from river logjams affect forest biodiversity and community successions.
\end{abstract}

\section{Introduction}

Understanding the spatial and temporal frequency of disturbance events is of great relevance to forest ecologists due to the importance of disturbance in shaping forest ecological processes (Asner, 2013). Forest disturbance and recovery cycles affect forest tree species distribution, community composition, ecosystem processes, biodiversity patterns, nutrient cycles, and the carbon balance (Chambers et al., 2013; Collins et al., 2012; Lewis et al., 2004; Phillips et al., 2004; White and Jentsch, 2001). Disturbance events are commonly classified along a continuum that goes from small-scale or frequent events, such as a tree fall that creates an open space, to large-scale and more rare events, such as large fires (White and Jentsch, 2001). The study of the geography of forest disturbance is particularly important in Amazonia, as it is home to about $10 \%$ of the world's biodiversity (Lewinsohn and Prado, 2005) and is among the most important terrestrial carbon sinks (Pan et al., 2011).
In Amazonia, where large forest fires are uncommon and there are no hurricanes, large-scale disturbance ( $>30 \mathrm{ha}$ ) is mostly caused by blowdowns (Nelson et al., 1994) that result from convective cloud downdrafts (Garstang et al., 1998). However, at least in western Amazonia, studies have shown that river activity can also be an important driver of forest disturbance and landscape reshaping via lateral erosion, overbank deposition, crevasse formation, and avulsions (Aalto et al., 2002; Kalliola et al., 1992; Lombardo, 2016; Salo et al., 1986).

In 1996, Gullison et al. (1996) observed that 48000 ha of forest in the Bolivian Amazon died off and were replaced by savannah due to scouring, flooding, and the deposition of alluvial sediments. These processes were caused by the overbank flow of the Cuberene River triggered by a logjam. Here, the term logjam refers to a partial or complete obstruction of a river channel caused by large wood (LW). Logjams can affect rivers and floodplains in several ways. They can decrease streamflow to such an extent that it leads to bank erosion and 


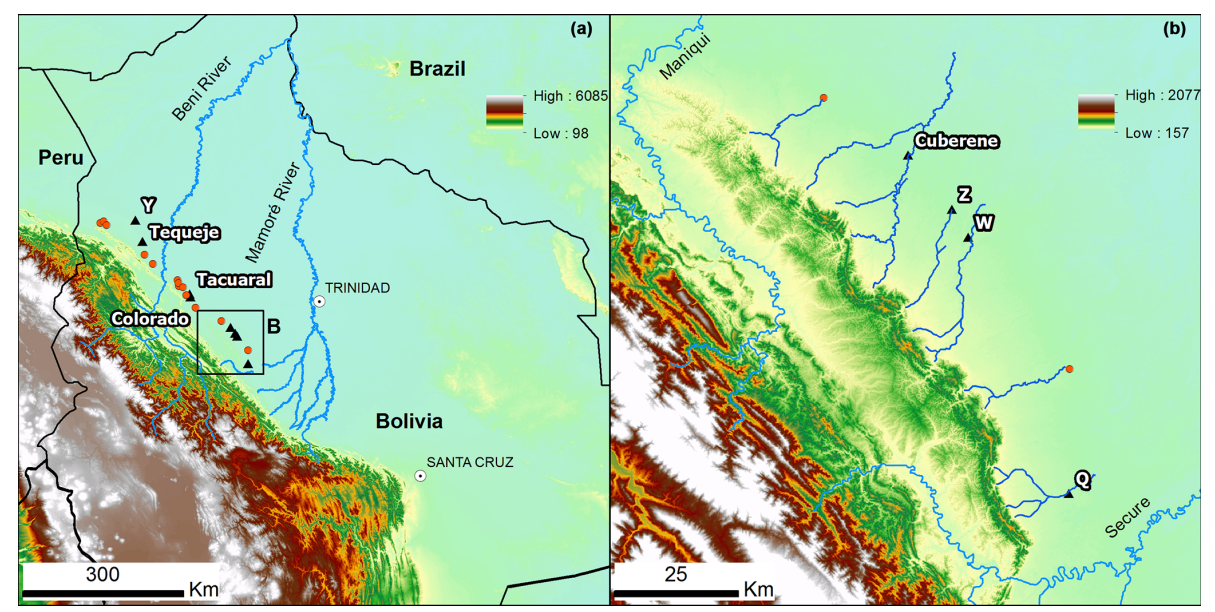

Figure 1. Study area and location of the rivers studied. The study area covers a strip of lowland forest that runs parallel to the Bolivian Andes (approximately $60 \mathrm{~km}$ wide $\times 400 \mathrm{~km}$ long). The black triangles identify the eight rivers analyzed here; the orange dots show the location of other rivers that experience logjam-induced floods but that have not been included in the analysis.

overbank flow, influencing channel-floodplain interactions and shaping the evolution of floodplain topography (Montgomery and Abbe, 2006; Sear et al., 2010; Wohl, 2013). Logjams are also an important component of river ecosystems, as they influence the transfer of solutes, mineral sediment, and organic material within the river channel system and between the river and the floodplain (Coe et al., 2009; Gurnell et al., 2002; Jochner et al., 2015; Wohl and Beckman, 2014). Despite the fact that logjams can have a dramatic impact on fluvial dynamics and fluvial-floodplain exchanges, their systematic study is relatively recent and has mostly been carried out in temperate zones (Dixon, 2016; Ruiz-Villanueva et al., 2016; Wohl, 2017, 2013). Very few studies have looked at the wood-river interactions in the neotropics, and these have mostly focused on headwater rivers (Cadol and Wohl, 2011, 2010; Iroumé et al., 2015; Wohl et al., 2012). Wohl (2017) reports that no field-based studies of LW in Amazonian rivers has ever been published in the English-language literature. Nevertheless, the observations of Gullison et al. (1996) do suggest that logjams are an important factor driving forest disturbance and biodiversity patterns in the Bolivian Amazon. For example, it has been shown that the increase in light that follows forest die-off events caused by logjams creates optimal conditions for the regeneration of mahogany (Swietenia macrophylla King), influencing its population dynamics (Gullison et al., 2003; Snook, 1996). Gullison et al. (1996) also reported the transformation of large areas of forest into savannah after being flooded. Despite these indications of the importance of logjams in shaping Bolivian forests, no further studies have followed up on Gullison et al. (1996). As of today, very little is known about the spatial extent and recurrence of these logjam-induced floods.

In this paper, I use a time series of Landsat imagery and field evidence to study logjam-induced floods and alluvial deposition in the Bolivian Amazon and map their extent and recurrence. Pre-Columbian earthworks in the area are identified and used to infer the past extent of logjam-induced floods. The aim of the paper is to describe the processes behind logjam-induced floods in the Bolivian Amazon and how they affect modern forest disturbance and recovery cycles and pre-Columbian land use in the past. The paper hopes to encourage debate and further research into a type of largescale Amazonian forest disturbance that has been largely overlooked in the literature.

\section{Methods}

The phenomena described by Gullison et al. (1996) - formation of logjam, forest die-off, and transformation of forest into savannah - can be studied through the visual analysis of remote sensing imagery (Gullison et al., 2003). In this paper, rivers affected by logjam-induced floods have been identified by analyzing the changes in river path and vegetation cover visible on the time-lapse application of Google Earth Engine (https://earthengine.google.com/timelapse/). The area of focus in this study is located between the flat Llanos and the Bolivian Andes, where lowland forests grow on relatively well-drained fluvial sediments. This area of lowland forests is approximately $60 \mathrm{~km}$ wide and $400 \mathrm{~km}$ long and runs parallel to the Bolivian Andes (Fig. 1). There are a total of 22 rivers that experience logjam-induced flooding (Fig. 1). These include all the small rivers between the Sécure River and the Beni and all but three of the rivers north of the Beni River.

A subset of eight of these rivers has been selected, and their evolution is analyzed throughout the period for which cloud-free Landsat images are available: from 1984 to 2016 (Table 1). These have been chosen in order to cover the whole area where the logjam-induced floods take place and in order to have a representation of rivers with different sizes. These 
Table 1. Overview of the dynamics of the logjams and their effect on the forest. "Yrs covered" is the number of years for which cloud-free Landsat imagery was available, "starting" is the year of the oldest cloud-free Landsat image available, "width" is the width of the river in meters, "N logjams" is the number of logjams detected for each river during the period 1984-2016, and "AFA" stands for "average flooded area" and is the average number of hectares that are flooded when there is a logjam-induced flood in a given river. TFA stands for "total flooded area" and is the number of hectares that have been flooded in total during the period 1984-2016. TFA is smaller than the sum of the AFA for all the years because large extents of land are often repeatedly flooded, so there is a significant overlap between areas flooded in different years. The "\% savannah" and "\% forest" values indicate the type of vegetation cover in 1984 (percentage of the TFA).

\begin{tabular}{lrrrrrrrr}
\hline River & Yrs covered & Starting & Width & N logjams & AFA & TFA & \% savannah & \% forest \\
\hline Tequeje & 29 & 1987 & 56 & 22 & 901 & 8921 & 20.4 & 79.6 \\
Y & 27 & 1984 & 93 & 11 & 1819 & 6977 & 22.6 & 77.4 \\
Tacuaral & 30 & 1984 & 22 & 21 & 505 & 3004 & 37 & 63 \\
Colorado & 30 & 1984 & 13 & 28 & 255 & 3646 & 2.9 & 97.1 \\
Z & 26 & 1986 & 13 & 13 & 221 & 1731 & 0 & 100 \\
W & 26 & 1986 & 18 & 13 & 491 & 4348 & 0 & 100 \\
Q & 29 & 1985 & 19 & 23 & 217 & 1568 & 0 & 100 \\
Cuberene & 27 & 1986 & 41 & 34 & 3007 & 21300 & 22.4 & 77.6 \\
\hline
\end{tabular}

eight rivers are the Tequeje, the Tacuaral, the Colorado, the Cuberene, and four other rivers, here referred to as Y, Z, W, and $\mathrm{Q}$, for which the toponyms could not be found (Fig. 1). The visual analysis of Landsat imagery allows for the identification of the areas where the water is diverted overbank and the river channel dries out. In the paper I refer to this phenomenon as river collapse. The location of the logjams (shown in Fig. 5) has been measured as the distance between the logjam and an arbitrary line parallel to the Andean piedmont, which serves as a common reference for all the rivers. The Landsat coverage of these eight rivers during the period 1984-2016 has been downloaded through the USGS LandsatLook Viewer (https://landsatlook.usgs.gov/). LandsatLook images are compressed and stretched full-resolution files derived from Landsat Level-1 data products. The band combination is 5, 4, 3 for Landsat 7 ETM+ and Landsat 4-5 TM; it is 6, 5, 4 for Landsat 8 OLI (https://landsat.usgs.gov/ landsatlook-images).

Fieldwork was carried out during the dry season of 2016 in order to confirm the observations described in Gullison et al. (1996) for the Cuberene River and validate the results of the visual analysis of the satellite images of the other rivers investigated here. The survey was conducted along the Tacuaral and Colorado rivers (Fig. 1) because of their easier access and the availability of local guides in these areas.

\section{Results}

The spatial characteristics of forest die-off triggered by logjam-induced floods are shown in Fig. 2. The reddish plumes diverging from the river channel show dead forest. Here trees have lost their leaves and the soil has been covered with alluvium or eroded. As can be seen in Figs. 2 and 3, logjams induce a total collapse of the river, as the totality of the river flow is diverted towards the forested floodplain, and the river channel downstream of the logjam dries up. The areas

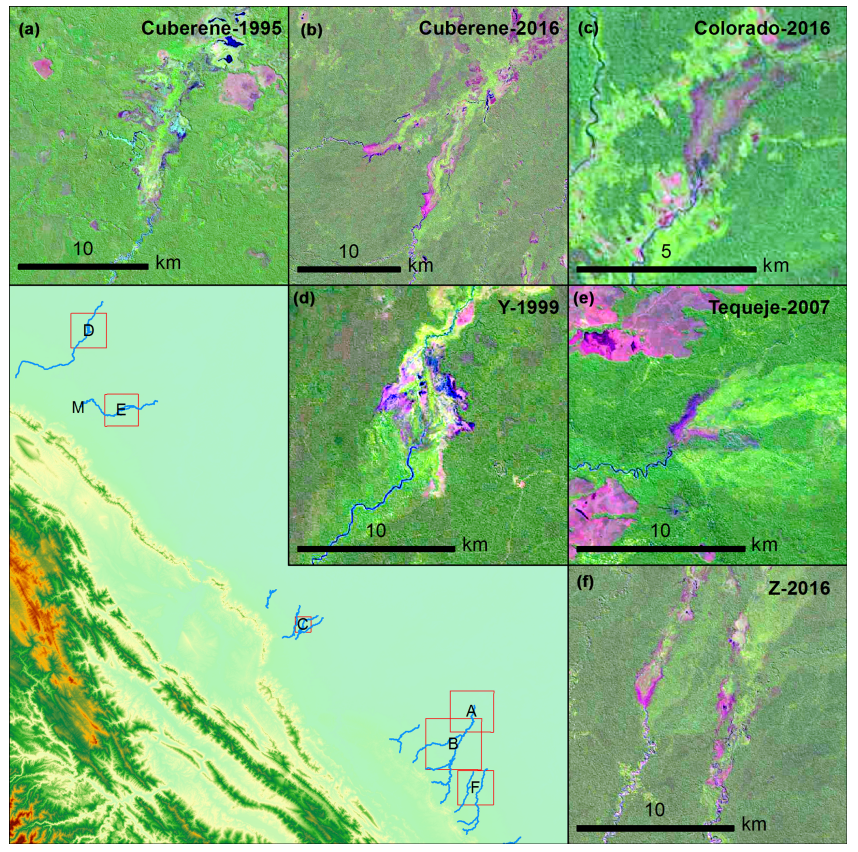

Figure 2. Examples of forest die-off events like the one described in Gullison et al. (1996). The reddish plumes diverging from the river channel indicate dead forest. Here, trees have lost their leaves and this causes a fall in near-infrared reflectance, which is shown in green in the RGB composition of the Landsat imagery (a-f), and an increase in mid-infrared reflectance (shown in red), which is mostly due to sediments. Non-forested, light green areas are covered by pioneer species; forested, light green areas are young secondary forests that have regrown after disturbance; forested, dark green areas are old-growth forests. Non-forested, reddish areas are savannah. Blue/black areas are water. All rivers flow from southwest to northeast. 


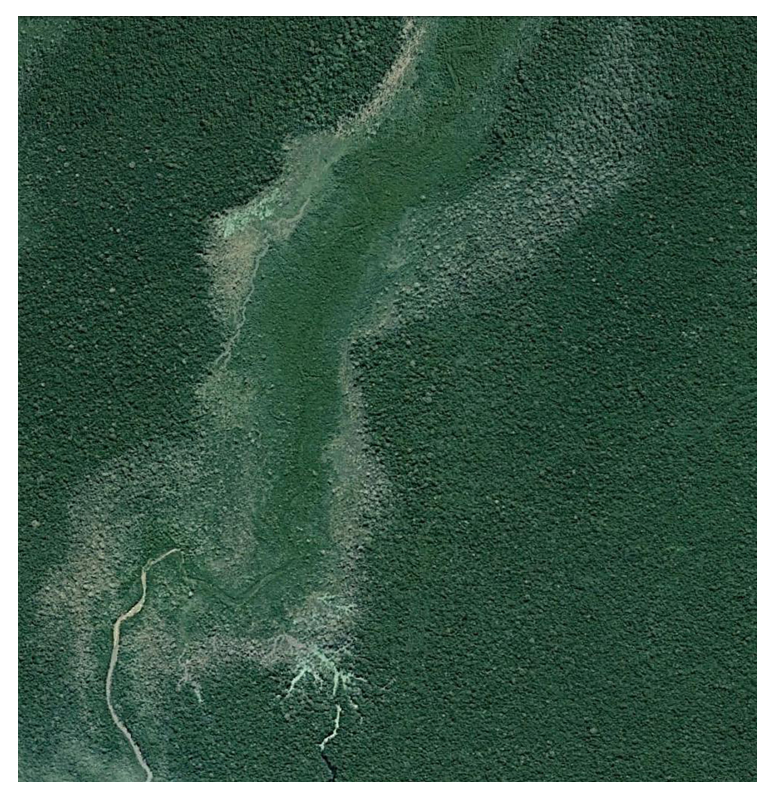

Figure 3. High-resolution image of forest die-off caused by a logjam in 2009 along the Cuberene River in the Chimane Forest. The grayish areas show dead forest and land that has been covered with sediments. Note how the totality of the water is diverted towards the forest. Image from Google Earth ${ }^{\circledR}$. The river flows from southwest to northeast.

where the forest has died off are also visible on the SRTM DEM as depressions of several meters (Fig. 4).

The analysis of Google Earth Engine time-lapse images identified 22 rivers in this area of the Bolivian Amazon that are affected by logjam-induced floods. The river logjams occur within a $400 \mathrm{~km}$ long belt along the eastern Andean piedmont, from latitude -15.9 to -13.5 . All but 2 of the 22 rivers affected by logjam-induced floods have their headwaters on the eastern side of two small pre-Andean mountain chains (Fig. 1). The northern one, between the Beni River and the Maniqui River, has a maximum elevation of about $1100 \mathrm{~m}$ a.s.l.; the southern mountain chain, between the Maniqui River and the Sécure River, has a maximum elevation of $650 \mathrm{~m}$ a.s.1. (Fig. 1b). Rivers originating in the southern part of the study area cross the Chimane Forest, where forest die-offs induced by logjams were first reported by Gullison et al. (1996) in the floodplain of the Cuberene River (Figs. 2a and 3). These small pre-Andean mountain chains act as a water divide between the basins of large rivers to the west (i.e. the Maniqui and Sécure rivers in Fig. 1b) and smaller rivers to the east.

In the eight rivers analyzed in greater detail from 1984 to 2016, 174 logjams causing river collapse and forest die-off have been identified and mapped (Fig. 5). The eight rivers show a similar pattern: a new logjam forms upriver from the previous one almost every year, unless an avulsion takes place and the sequence restarts at a greater distance from the Andes (i.e. the rivers Colorado, Cuberene, Tacuaral, and

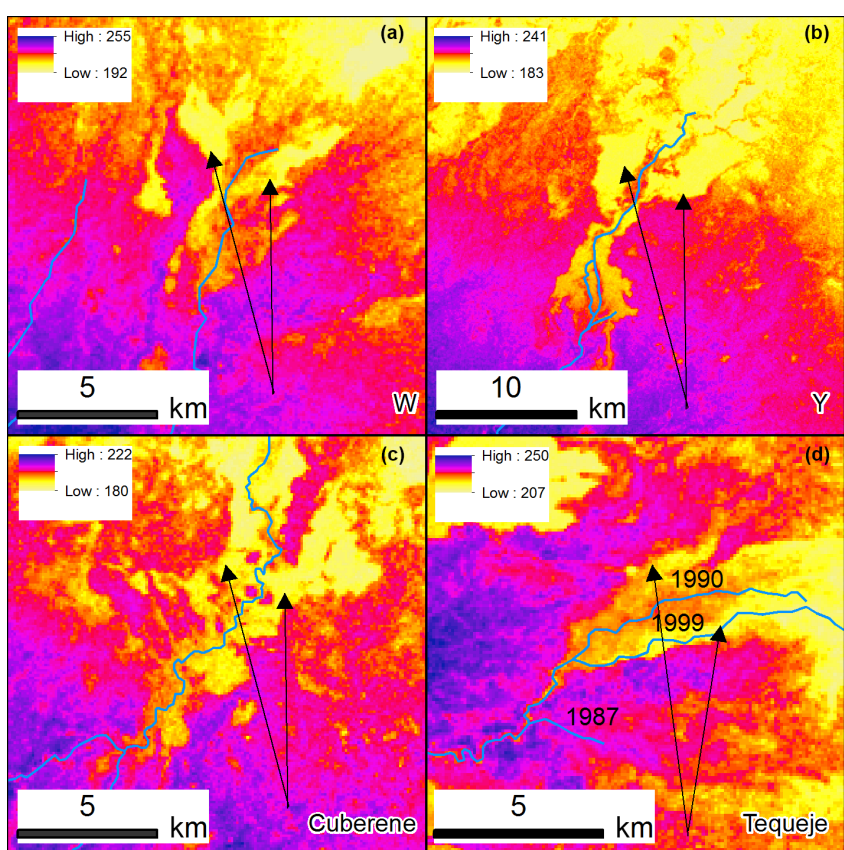

Figure 4. SRTM image of four areas where logjam-induced floods resulted in the death of the forest. SRTM imagery shows the situation, in the year 2000, for the rivers Cuberene, Tequeje, W, and Y. At any given point, the SRTM digital elevation model gives the elevation of the canopy, not the elevation of the soil; therefore, deforested patches are visible as depressions (here rendered as yellow areas surrounded by red). The arrows indicate the areas where forest has been replaced by herbaceous vegetation.

Tequeje in Fig. 5). The average distance between successive logjams ranges from $1170 \mathrm{~m}$, in the case of the Cuberene, to $224 \mathrm{~m}$, in the case of the Colorado.

The river Tequeje, a left-hand tributary of the Beni River, is the second largest among the eight studied. During the period 1987-2016, there were 22 logjams forming along its course and the river underwent two avulsions (Figs. 5 and 6). This river shows all the features that characterize the main traits of the behavior of the other rivers affected by logjam-induced floods in the study area. In 1987 (Fig. 6a) a logjam-induced flood resulted in the death of 173 ha of forest in a characteristic V shape, with the vertex of the "V" placed on the logjam and the two sides branching out on either side of the channel. The V shape is probably caused by two factors: (1) the fact that the forest in the inner part of the $\mathrm{V}$ had already died off due to the floods and sediment deposition in previous years, and in 1987 it was covered with pioneer, fast-growing vegetation (i.e. Tessaria integrifolia Ruiz \& Pav.), and (2) the topographic high of sedimentary lobes left by previous floods, which favors the diversion of the water on both sides of the channel. In 1990, a new area was flooded following the river avulsion of 1989 (Fig. 6b). Here the dead forest has an oval shape, as this is the beginning of a new series of upstream logjam formations and no previous alluvium has diverted the 

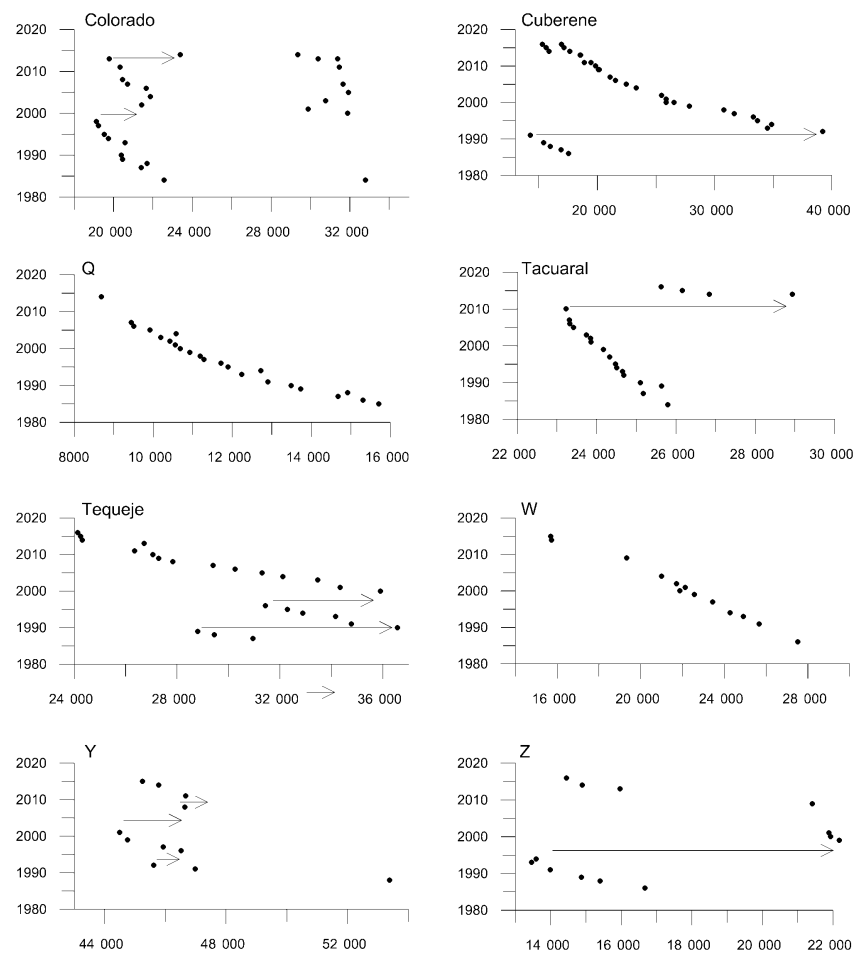

Figure 5. Locations of logjams in the eight rivers analyzed here. The year of logjam formation ( $Y$ axis) is plotted against the logjam's distance from the Andean piedmont in meters ( $X$ axis). The arrows indicate river avulsions.

overbank water. The area of savannah visible in 1987 is reduced by 1990 and no longer visible in 2000 (Fig. 6c). After the avulsion in 1996, logjams occur to the east of the area as shown in Fig. 2, with the location moving upriver every year. By 2016, most of the area where the forest died off in 1987 is forested again. In 2016, the logjam is closer to the Andes than at any other moment during the 29 years studied. The sediments deposited between 2014 and 2016 have dammed two small tributaries that have been transformed into small lakes (Fig. 2e). Two small areas, which were forested in 1987, have been transformed into savannah after being constantly flooded between 2011 and 2016 (Fig. 6a, d, and e). A total of about 8900 ha of land have been flooded at least once by the Tequeje River during the 29 years analyzed. Of these, 7100 ha were forested and 1800 ha were savannah in 1987 (Table 1). The Tequeje channel shows a meandering pattern from the point at which it enters the alluvial plains to about $4 \mathrm{~km}$ upriver from the 2016 logjam (Fig. 7). From this point onwards, it has an immature channel. The point at which the Tequeje loses the meandering pattern probably indicates the location of the most upriver logjam in the past; downriver from this point the avulsive pattern begins. In the 2016 imagery, it can be seen that a new course is about to be established (Fig. 7). The Cuberene River causes the most spectacular transformation of the landscape, with log-

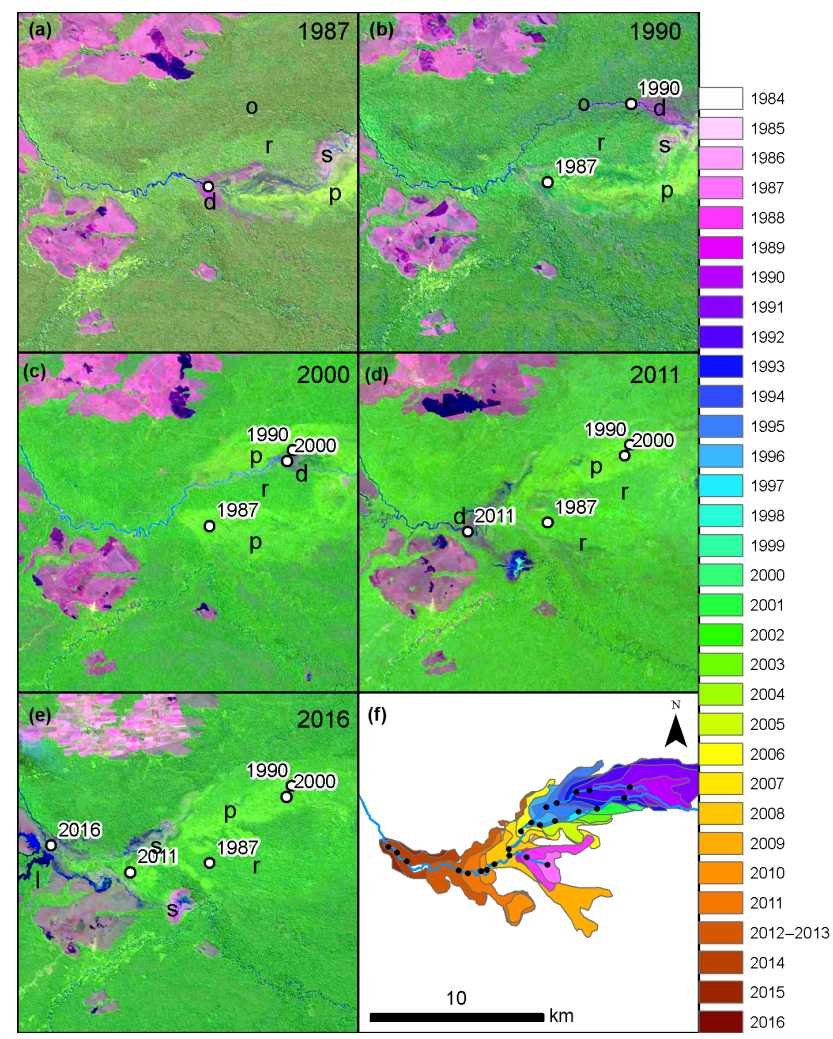

Figure 6. Evolution of the Tequeje River from 1987 to 2016 . The river flows from west to east. Inset (a) shows the situation in 1987, when the coverage of cloud-free Landsat imagery began. Lowercase letters indicate land cover: "o" is for old-growth forest, "p" is for pioneer plants, " $\mathrm{r}$ " is for recently regrown forest, " $\mathrm{d}$ " is for recently dead forest, " $\mathrm{s}$ " is for savannah, and "l" is for lakes. Inset (e) shows the most recent image available with the location of the logjam in 2016. Inset (f) shows the location of the logjams on a yearly basis from 1987 to 2015 and the extension of dead forest as a result of the flooding. Logjams formed from 1996 to 1999 and flooded regions are located to the east of the area shown here.

jams forming further and further upstream until they reach the Cuberene tributaries where the process continues (Fig. 8). Large areas that were forested in 1995 are transformed into savannah by 2016 because of the repeated flooding. Fieldwork was conducted during the dry season in August 2016 along the rivers Tacuaral and Colorado. A few tens of meters upriver from the 2016 logjam in the Colorado River (Figs. 9 and 10), sand was deposited by overbank flow and the area was immediately colonized by parajobobo (Tessaria integrifolia Ruiz \& Pav.). Parajobobo is a pioneer, fast-growing species that tends to colonize sand deposits along fluvial channels by forming monospecific stands of the same age (Neiff, 2004). Figure 10 shows a $2 \mathrm{~m}$ thick sand layer, which was deposited overnight at the end of January 2016 (Macario Huanca Quispe, community of Inka Agropecuaria, personal communication, 2016). The parajobobo trees behind the hut in Fig. 10 are 7 months old. The plant communities that 


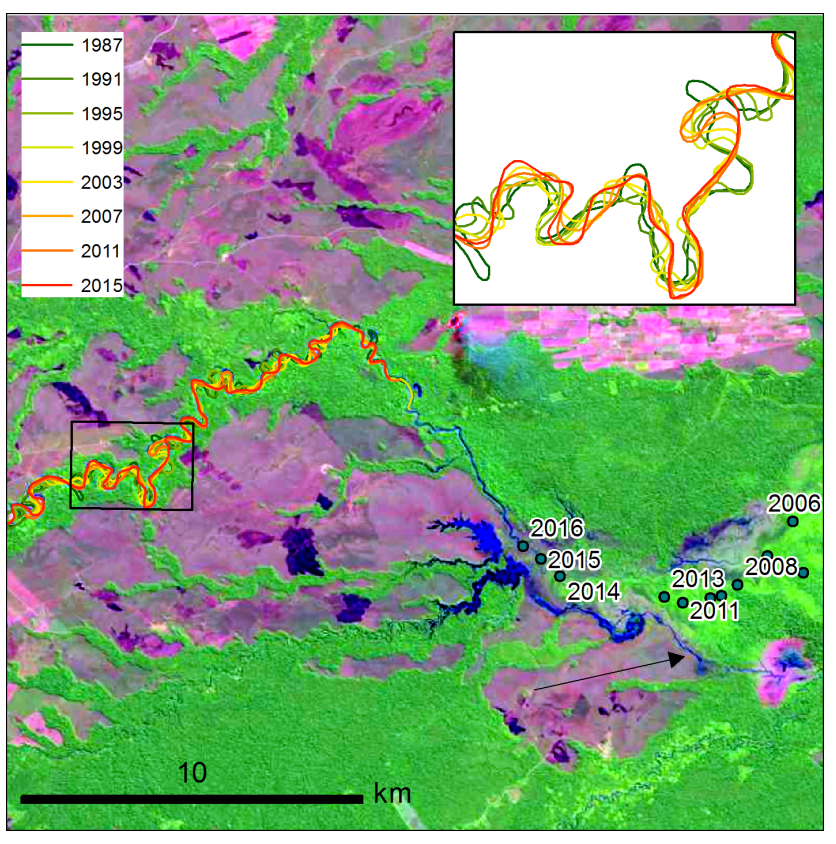

Figure 7. Landsat image of the Tequeje River in 2016. The river flows from west to east. The green dots with the red labels indicate the location and year of past logjams. The inset shows the evolution of the river channel from 1987 to 2015 at 4-year intervals.

colonize the clearance following the forest die-off (Fig. 11) are the same as the communities that colonize fluvial deposits along the Mamoré River. Besides parajobobo, there is an abundance of Echinochloa polystachya, Cecropia sp. (Ambaibo), Heliconia sp. (Patucú), and Gynerium sagittatum (Maldonado and Beck, 2004). After the sand is deposited, the water moves across the forested areas, eroding the topsoil and exposing tree roots. Scouring forms many small channels (Fig. 12). The survey along the Colorado River revealed a paleosol associated with pre-Columbian pottery. The paleosol, located about $4 \mathrm{~m}$ below the top of the riverbank, has been radiocarbon dated to $1390 \pm 43$ cal yrs BP. Pre-Columbian raised fields, which are ancient elevated platforms that were used for agriculture (Lombardo et al., 2011; Rodrigues et al., 2016), are visible in Google Earth imagery a few kilometers downriver from the areas affected by the logjam-induced floods of the Cuberene River (Fig. 13). Figure 13 shows that pre-Columbian earthworks (raised fields and causeways) are found within the area crossed by paleochannels of the Cuberene River and other small rivers to the south.

\section{Discussion}

Logjam-induced floods have been largely overlooked as important agents of forest disturbance in Amazonia. The analysis of time series of Landsat imagery shows that, in a vast area of lowland forest (approximately $60 \times 400 \mathrm{~km}$ ) run-

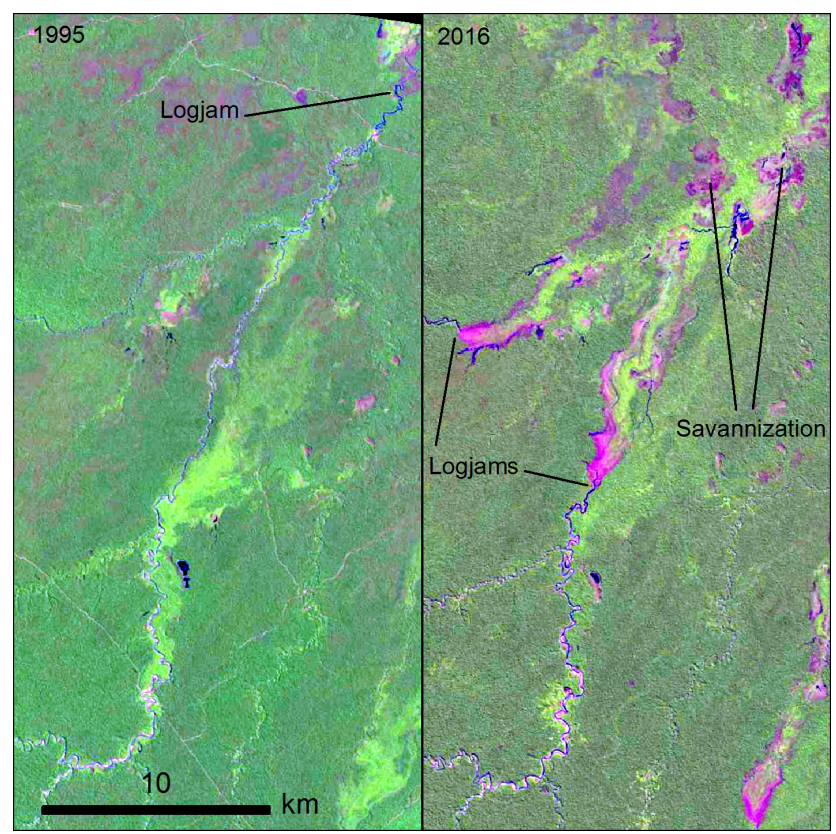

Figure 8. Evolution of the Cuberene River. The river flows from southwest to northeast. From 1995 to 2016, the location of the logjams propagated upriver, along the two rivers that form the $\mathrm{Cu}$ berene. By 2016, large areas that were forested in 1995 had been transformed into savannah. An east-west road crossing the $\mathrm{Cu}-$ berene in 1995 is completely obliterated in the 2016 image. Also notice how the light green areas in early stages of the successional process in 1995 are already forested by 2016 .

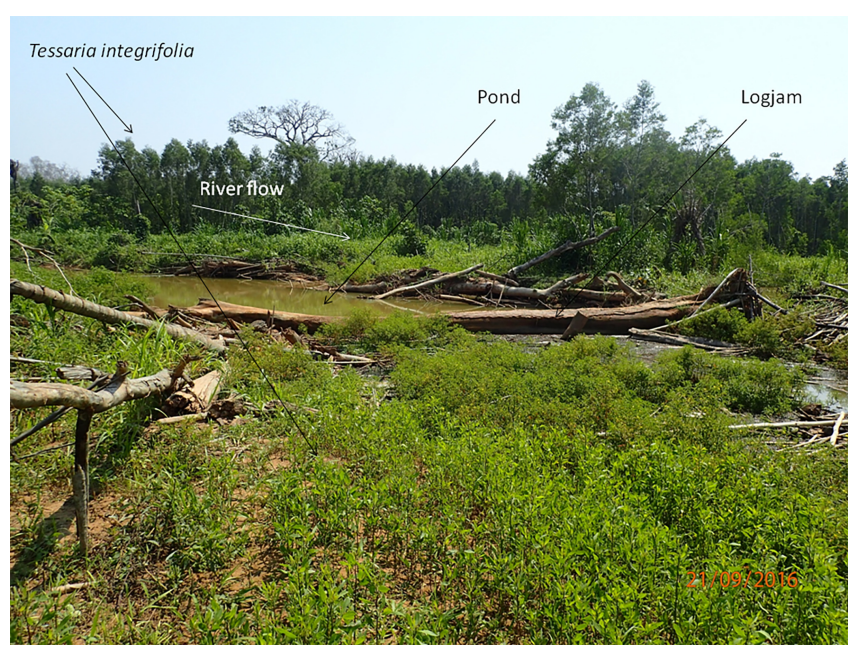

Figure 9. Logjam formed in 2016 in the Colorado River. The logjam spans the entire channel and has low porosity.

ning parallel to the eastern Andean piedmont in Bolivia, logjam-induced floods are a major driver of forest disturbance. Logjam-induced floods drive a characteristic form of forest disturbance, as they affect hundreds of hectares of forest recurrently, in most cases on a yearly basis. This is a type 


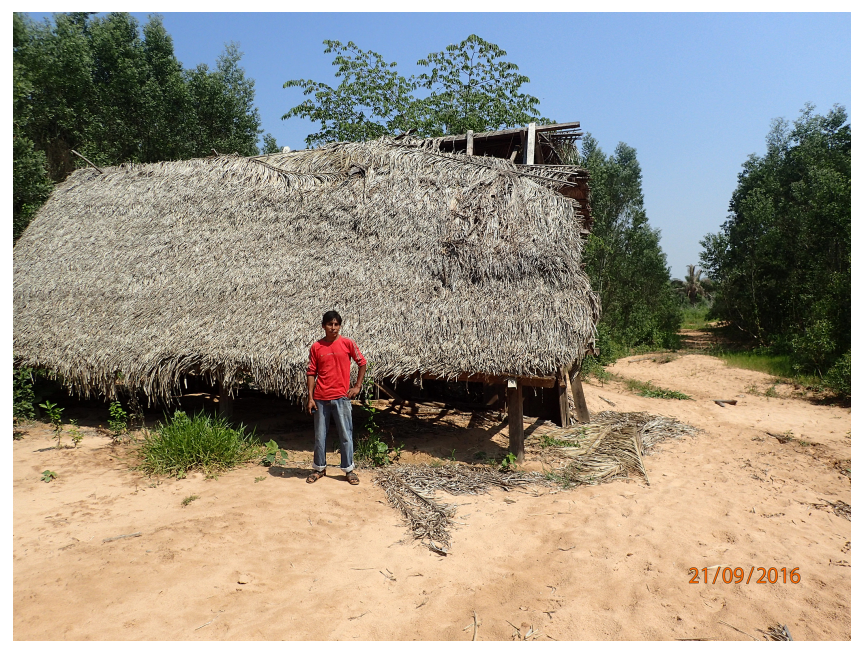

Figure 10. Sand layer deposited overnight in 2016 by the Colorado River in the community of Inka Agropecuaria. The posts of the hut were originally $3 \mathrm{~m}$ above the surface; after the deposition only the topmost meter remained above the sand. The house is about $100 \mathrm{~m}$ from the Colorado River and about $1 \mathrm{~km}$ upriver from the point at which the 2016 logjam formed (Fig. 3). The trees behind and on the right of the house are 7-month-old parajobobos.

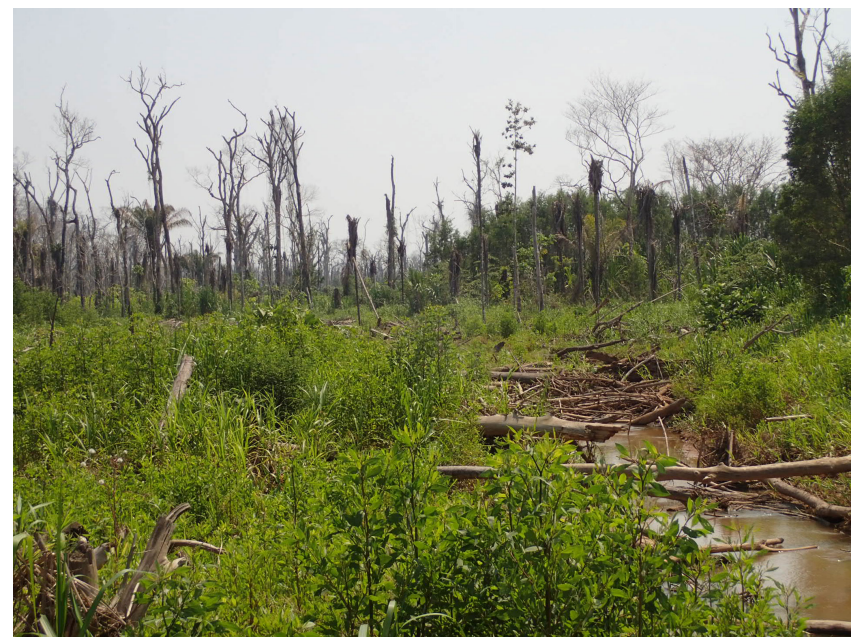

Figure 11. Forest die-off due to the 2016 flood of the Colorado River rapidly being replaced by Echinochloa polystachya and Tessaria integrifolia.

of large-scale disturbance that can be classified as intense and frequent (Turner et al., 1998).

In the Chimane Forest and its surroundings, PanequeGálvez et al. (2013) have estimated that, during the period 1986 to 2009 , a total of 26000 ha of old-growth forest was lost due to human activities. During the same period, the $\mathrm{Cu}$ berene logjam-induced floods affected 18500 ha. The rate of forest disturbance caused by rivers here is therefore comparable to the current rates of deforestation driven by the expansion of the agricultural frontier.

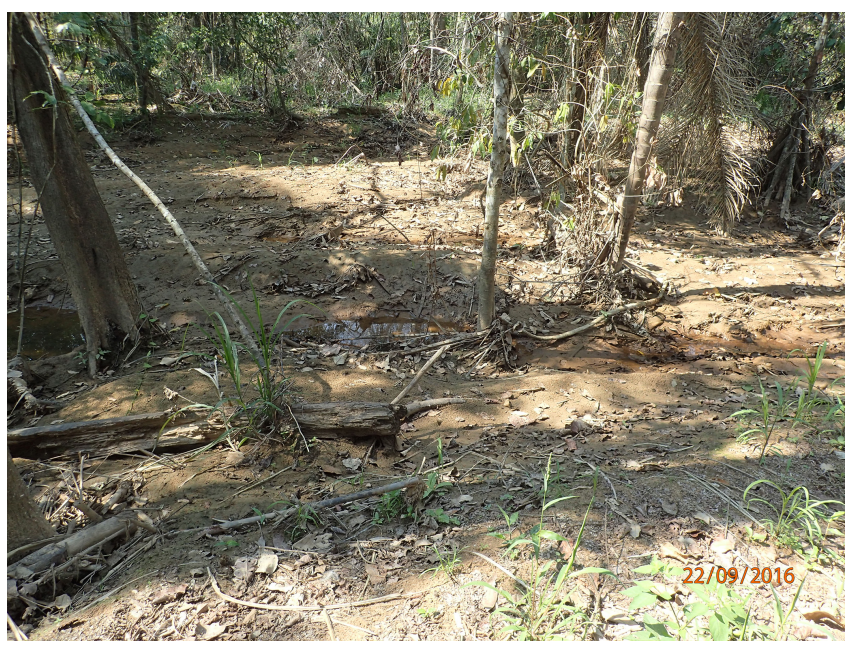

Figure 12. Scouring channels downriver from the logjam in the Tacuaral River in 2016.

Forest ecological processes, particularly tropical forest carbon sinks, are assessed by monitoring relatively small plots of forest over relatively long periods of time $(\sim 30 \mathrm{yrs}$; Lewis et al., 2004; Phillips et al., 2004). However, to what extent the long-term monitoring of small plots can take into account large-scale events is controversial (Chambers et al., 2009; Espírito-Santo et al., 2014). This study shows an example of an area where the monitoring of small plots can lead to critically skewed results if logjam-induced forest disturbance is not taken into account. The high rate of logjaminduced forest disturbance could be the reason for the yet unexplained low tree biodiversity observed in the Chimane Forest (Gullison et al., 1996); it could also explain why current models are unable to capture a large part of the floristic variation here (Guèze et al., 2013).

It is known that two of the most important factors controlling the formation of logjams are the recruitment of LW and the relation between the size of the LW and the width of the river channel (Gurnell et al., 2002; Wohl, 2013). The rivers studied here have very high meander migration rates (see Fig. 7) and hence can recruit a large amount of wood because of the lateral erosion of forested areas. They have very small mountain catchments; hence they enter the alluvial plains when they are still not very wide. Due to uplift events that have occurred north of the study area (Lombardo, 2014), the region is also extremely flat and the rivers have a relatively low transport capacity and a propensity toward river channel siltation (Lombardo, 2016). All these conditions contribute to the formation of channel-spanning logjams. Although the collapsing of the river on an almost yearly basis is restricted to the small rivers analyzed here, channel-spanning logjams causing river avulsions have also been reported in larger Bolivian rivers, such as the Maniqui and the Sécure (Lombardo, 2016). In the Bolivian Amazon, the behavior of large rivers, such as the Beni and the Mamoré, is significantly differ- 


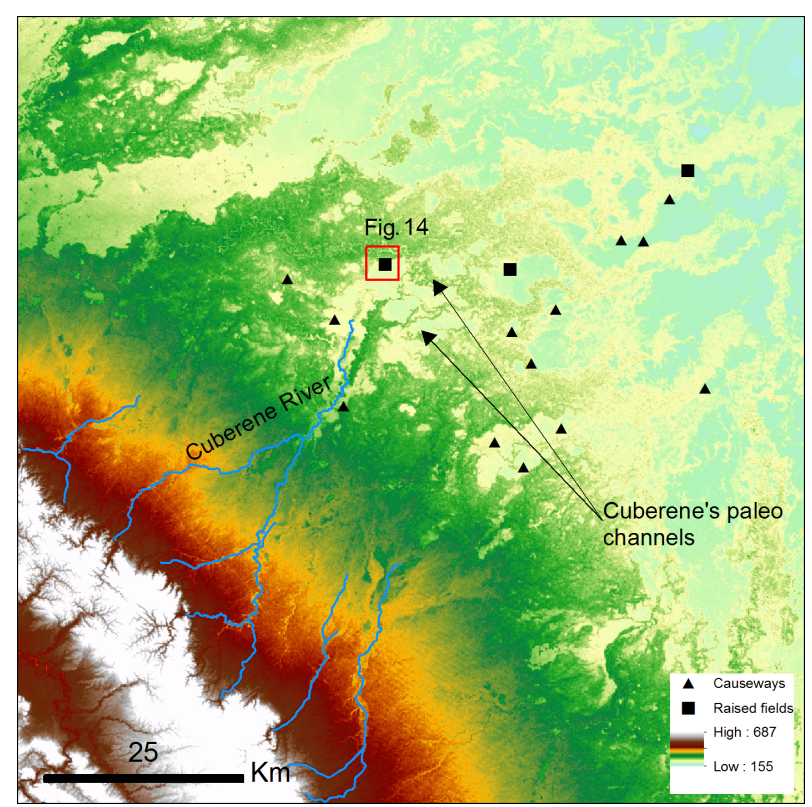

Figure 13. Location of pre-Columbian earthworks in the Chimane Forest and the location in Fig. 14. The triangles indicate the location of pre-Columbian causeways and the squares show the location of raised fields, which are pre-Columbian structures built to allow agriculture in otherwise flooded areas.

ent from that of their tributaries. The Beni and the Mamore are characterized by high sedimentary loads, high meandering rates, and increasing discharge downstream (Aalto et al., 2003; Constantine et al., 2014; Guyot et al., 1996). They do not form logjams and they undergo avulsions on a millennial scale, mostly driven by neotectonic events and/or changes in climate (Dumont and Fournier, 1994; Lombardo, 2014; Plotzki et al., 2013). In contrast, their smaller tributaries often show downstream decreases in discharge, which is accompanied by the frequent formation of crevasses that often evolve into complete river avulsions (Lombardo, 2016). The 22 rivers studied here show similarities with some of the Mamoré tributaries (i.e. the Maniqui and Sécure rivers as noted above), but are unique in the impact they have on the forest and in the fact that logjam-induced floods occur on an almost yearly basis. Further studies are needed in order to understand whether, over time, new logjams always form further upstream or whether, in some cases, existing logjams "grow upstream" by the addition of new wood. It is also still unclear what happens during years when logjams maintain their position. Is it that not enough wood is added or is it that new logs replace old ones, which decay fast (Dixon and Sear, 2014)? To my knowledge, there are no other studies on logjam formation in lowland tropical rivers; therefore it is difficult to assess to what extent the processes that take place in this part of the Bolivian Amazon are specific to this area due to its hydrological context or are typical of other small tropical meandering rivers.

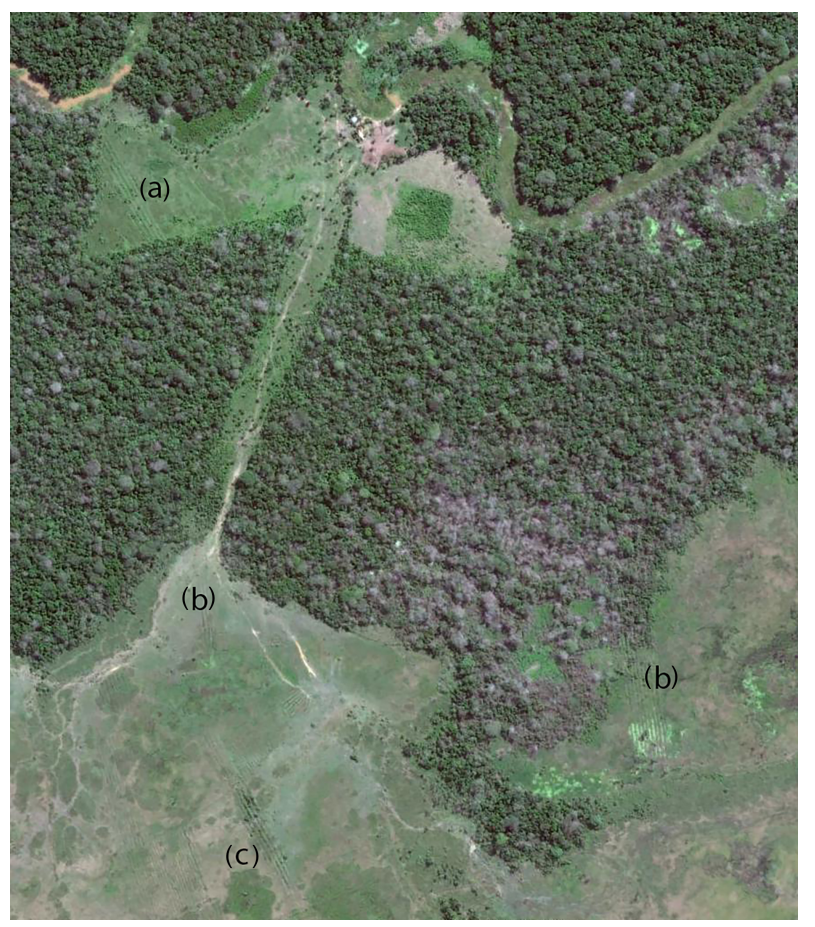

Figure 14. The location of raised fields in the proximity of a $\mathrm{Cu}-$ berene River paleochannel (for location see the red box in Fig. 12). (a) Raised fields built in the forested upland that grows over the fluvial levee, (b) raised fields built across the current forest-savannah ecotone, and (c) fields built in the seasonally flooded savannah.

The presence of pre-Columbian earthworks in an area crossed by the Cuberene River paleochannels (Fig. 13) suggests, on the one hand, that the preferential location for logjam formation and the deposition of alluvium has moved westward, at least since the construction of the earthworks. Otherwise these would have been destroyed or, more likely, never have been built in an area under such a high risk of catastrophic floods in the first place. On the other hand, the presence of Cuberene paleochannels in the very same area as the pre-Columbian earthworks suggests that, prior to the construction of the raised fields, logjams were less frequent or happened further to the east than their modern location. Raised fields were built to mitigate the risk posed by extreme floods (Lombardo et al., 2011) and their geometry, size, and location responded to the local hydrology (Rodrigues et al., 2015, 2016). The fact that raised fields in the Cuberene area were built along the whole slope that goes from the former levees of the Cuberene River to the former backswamps (Fig. 13) suggests that the local hydrology was highly variable in pre-Columbian times. This is to be expected in an area subject to frequent river avulsions occurring just a few kilometers upriver. The paleosol in the riverbank of the Colorado River containing pre-Columbian pottery dated to $1390 \pm 43 \mathrm{cal}$ yrs BP is buried under a $4 \mathrm{~m}$ layer of sediment. This shows the high depositional rate of these 
rivers, leading to the burial of many archaeological sites in the region. This example highlights the importance of taking into account river dynamics when analyzing the spatial patterns of pre-Columbian settlements in the region. In recent years, the Andean piedmont has been increasingly occupied by small communities of campesinos from the Andean region that clear the forest to practice agriculture (Paneque-Gálvez et al., 2013). The agricultural frontier is now expanding eastward from the road that links the towns of Yucumo and Rurrenabaque, running along the part of the Andean piedmont north of the Maniqui River (Fig. 1). This is the area where LW is recruited by the lateral erosion of forested riverbanks; therefore, the modern land-use practices here will probably reduce forest recruitment and cause the reduction and eastward migration of the logjam formations in the near future.

Most of the studies on logjams have been carried out for rivers in temperate regions, where fluvial dynamics have been impacted by human activity throughout history and logjam dynamics differ from tropical regions (Wohl, 2013). However, dynamics similar to the ones described here for the Bolivian Amazon have also been reported for rivers in temperate latitudes (Kramer et al., 2017; Triska, 1984; Wohl, 2014), suggesting that what we currently see in Bolivia could have been more common in temperate regions prior to the anthropic modification of river catchments (Wohl, 2014). The almost pristine environmental conditions of the Bolivian Amazon and the recent change in land use here offer an excellent natural laboratory to study the dynamics of wood in lowland tropical rivers, the process of forest disturbance and community successions, and how changes in LW recruitment affect both river dynamics and tree communities. The stratigraphic setting in the area of logjam-induced floods in the Bolivian Amazon could provide a template to help reconstruct similar processes that could have been more frequent in temperate regions in the past.

\section{Conclusions}

This paper analyses the dynamics of logjam formation in tropical meandering rivers in southwestern Amazonia. The study focuses on rivers that cause logjam-induced floods in an area (approximately $60 \times 400 \mathrm{~km}$ ) of lowland forest that stretches parallel to the Andean piedmont in Bolivia. The analysis of remote sensing imagery shows the existence of 22 such rivers, representing practically the totality of the smaller rivers in the area. These rivers are characterized by (i) being relatively small when they enter the alluvial plains (hence their width is similar to the height of the trees they transport), (ii) having a high meandering rate that causes lateral erosion of forested areas and a high recruitment rate of LW, and (iii) flowing across a very gentle slope, which reduces their capacity to transport LW. The study shows that logjam-induced floods are a major driver of forest disturbance in the Bolivian Amazon. Large logjam-induced floods follow a pattern that is consistent in all the rivers studied: channel-spanning logjams form on an almost yearly basis, always further upriver, until an avulsion takes place and the process restarts in a new location within the alluvial plains at a greater distance from the Andes. Each logjam-induced flood is characterized by (i) the sudden deposition of a thick sand layer a few tens of meters upriver from the logjam and (ii) a V-shaped area where forest dies off and is replaced by pioneer plants or transformed into savannah grassland if repeatedly flooded. This study shows that large and frequent floods triggered by logjams have a major impact on forest disturbance and recovery cycles and can potentially explain local floristic variations. This case study offers a unique opportunity for further research on how LW affects river behavior in lowland tropical settings and how large and frequent forest disturbance events resulting from logjams affect forest biodiversity and community successions.

Data availability. Landsat imagery data were obtained from the USGS LandsatLook Viewer (https://landsatlook.usgs.gov/, USGS, 2017).

Files containing the digitalized locations of logjams and river paths are available upon request from the author of this paper.

Competing interests. The author declares that he has no conflict of interest.

Acknowledgements. The present study has been funded by the Swiss National Science Foundation (SNSF) grant no P300P2158459/1 and by the European Union's Horizon 2020 research and innovation program (Marie Skłodowska-Curie actions; EU project 703045). I would like to thank Macario Huanca Quispe for helping me in the field, Frank Mayle for helping me with the identification of the vegetation, and Elisa Canal-Beeby for helping improve earlier versions of the paper. I would also like to thank the handling editor, Rolf Aalto, one anonymous reviewer, Ellen Wohl, and Simon Dixon for the constructive comments they provided.

Edited by: Rolf Aalto

Reviewed by: Ellen Wohl and one anonymous referee

\section{References}

Aalto, R., Dunne, T., Nittrouer, C. A., Maurice-Bourgoin, L., and Montgomery, D. R.: Fluvial transport of sediment across a pristine tropical foreland basin: channel-floodplain interaction and episodic floodplain deposition, in: The Structure, Function and Management Implication of Fluvial Sedimentary Systems, edited by: Dyer, F. J., Thoms, M. C., and Olley, J. M., IAHS Publication, 276, 339-344, 2002.

Aalto, R., Maurice-Bourgoin, L., Dunne, T., Montgomery, D. R., Nittrouer, C. A., and Guyot, J.-L.: Episodic sediment accumulation on Amazonian flood plains influenced by El Niño/Southern Oscillation, Nature, 425, 493-497, 2003. 
Asner, G. P.: Geography of forest disturbance, P. Natl. Acad. Sci. USA, 110, 3711-3712, 2013.

Cadol, D. and Wohl, E.: Wood retention and transport in tropical, headwater streams, La Selva Biological Station, Costa Rica, Geomorphology, 123, 61-73, 2010.

Cadol, D. and Wohl, E.: Coarse sediment movement in the vicinity of a logjam in a neotropical gravel-bed stream, Geomorphology, 128, 191-198, 2011.

Coe, H. J., Kiffney, P. M., Pess, G. R., Kloehn, K. K., and McHenry, M. L.: Periphyton and invertebrate response to wood placement in large pacific coastal rivers, River Res. Appl., 25, 1025-1035, 2009.

Chambers, J. Q., Negrón-Juárez, R. I., Hurtt, G. C., Marra, D. M., and Higuchi, N.: Lack of intermediate-scale disturbance data prevents robust extrapolation of plot-level tree mortality rates for old-growth tropical forests, Ecol. Lett., 12, E22-E25, 2009.

Chambers, J. Q., Negron-Juarez, R. I., Marra, D. M., Di Vittorio, A., Tews, J., Roberts, D., Ribeiro, G. H. P. M., Trumbore, S. E., and Higuchi, N.: The steady-state mosaic of disturbance and succession across an old-growth Central Amazon forest landscape, P. Natl. Acad. Sci. USA, 110, 3949-3954, 2013.

Collins, B. D., Montgomery, D. R., Fetherston, K. L., and Abbe, T. B.: The floodplain large-wood cycle hypothesis: A mechanism for the physical and biotic structuring of temperate forested alluvial valleys in the North Pacific coastal ecoregion, Geomorphology, 139-140, 460-470, 2012.

Constantine, J. A., Dunne, T., Ahmed, J., Legleiter, C., and Lazarus, E. D.: Sediment supply as a driver of river meandering and floodplain evolution in the Amazon Basin, Nat. Geosci., 7, 899-903, 2014.

Dixon, S. J.: A dimensionless statistical analysis of logjam form and process, Ecohydrology, 9, 1117-1129, 2016.

Dixon, S. J. and Sear, D. A.: The influence of geomorphology on large wood dynamics in a low gradient headwater stream, Water Resour. Res., 50, 9194-9210, 2014.

Dumont, J. F. and Fournier, M.: Geodynamic environment of Quaternary morphostructures of the subandean foreland basins of Peru and Bolivia: Characteristics and study methods, Quatern. Int., 21, 129-142, 1994.

Espírito-Santo, F. D. B., Gloor, M., Keller, M., Malhi, Y., Saatchi, S., Nelson, B., Junior, R. C. O., Pereira, C., Lloyd, J., Frolking, S., Palace, M., Shimabukuro, Y. E., Duarte, V., Mendoza, A. M., López-González, G., Baker, T. R., Feldpausch, T. R., Brienen, R. J. W., Asner, G. P., Boyd, D. S., and Phillips, O. L.: Size and frequency of natural forest disturbances and the Amazon forest carbon balance, Nat. Commun., 5, 3434, https://doi.org/10.1038/ncomms4434, 2014.

Garstang, M., White, S., Shugart, H. H., and Halverson, J.: Convective cloud downdrafts as the cause of large blowdowns in the Amazon rainforest, Meteorol. Atmos. Phys., 67, 199-212, 1998.

Guèze, M., Paneque-Gálvez, J., Luz, A. C., Pino, J., Orta-Martínez, M., Reyes-García, V., and Macía, M. J.: Determinants of tree species turnover in a southern Amazonian rain forest, J. Veg. Sci., 24, 284-295, 2013.

Gullison, R. E., Panfil, S. N., Strouse, J. J., and Hubbell, S. P.: Ecology and management of mahogany (Swietenia macrophylla King) in the Chimanes Forest, Beni, Bolivia, Bot. J. Linn. Soc., 122, 9-34, 1996.
Gullison, R. E., Vriesendorp, C., and Lobo, A.: Effects of LargeScale Flooding on Regeneration of Big-Leaf Mahogany in the Bolivian Amazon, in: Big-Leaf Mahogany: Genetics, Ecology, and Management, edited by: Lugo, A. E., Figueroa Colón, J. C., and Alayón, M., Springer New York, New York, 2003.

Gurnell, A. M., Piégay, H., Swanson, F. J., and Gregory, S. V.: Large wood and fluvial processes, Freshwater Biol., 47, 601-619, 2002.

Guyot, J. L., Filizola, N., Quintanilla, J., and Cortez, J.: Dissolved solids and suspended sediment yields in the Rio Madeira basin, from the Bolivian Andes to the Amazon, Exeter, 1996.

Iroumé, A., Mao, L., Andreoli, A., Ulloa, H., and Ardiles, M. P.: Large wood mobility processes in low-order Chilean river channels, Geomorphology, 228, 681-693, 2015.

Jochner, M., Turowski, J. M., Badoux, A., Stoffel, M., and Rickli, C.: The role of log jams and exceptional flood events in mobilizing coarse particulate organic matter in a steep headwater stream, Earth Surf. Dynam., 3, 311-320, https://doi.org/10.5194/esurf-3311-2015, 2015.

Kalliola, R., Salo, J., Puhakka, M., Rajasilta, M., Häme, T., Neller, R. J., Räsänen, M. E., and Danjoy Arias, W. A.: Upper amazon channel migration, Naturwissenschaften, 79, 75-79, 1992.

Kramer, N., Wohl, E., Hess-Homeier, B., and Leisz, S.: The pulse of driftwood export from a very large forested river basin over multiple time scales, Slave River, Canada, Water Resour. Res., 53, 1928-1947, 2017.

Lewinsohn, T. M. and Prado, P. I.: How Many Species Are There in Brazil? Cuantas Especies Hay en Brasil?, Conserv. Biol., 19, 619-624, 2005.

Lewis, S. L., Phillips, O. L., Baker, T. R., Lloyd, J., Malhi, Y., Almeida, S., Higuchi, N., Laurance, W. F., Neill, D. A., Silva, J. N. M., Terborgh, J., Torres Lezama, A., Vásquez Martinez, R., Brown, S., Chave, J., Kuebler, C., Núñez Vargas, P., and Vinceti, B.: Concerted changes in tropical forest structure and dynamics: evidence from 50 South American long-term plots, Philos. T. R. Soc. B, 359, 421-436, 2004.

Lombardo, U.: Neotectonics, flooding patterns and landscape evolution in southern Amazonia, Earth Surf. Dynam., 2, 493-511, https://doi.org/10.5194/esurf-2-493-2014, 2014.

Lombardo, U.: Alluvial plain dynamics in the southern Amazonian foreland basin, Earth Syst. Dynam., 7, 453-467, https://doi.org/10.5194/esd-7-453-2016, 2016.

Lombardo, U., Canal-Beeby, E., Fehr, S., and Veit, H.: Raised fields in the Bolivian Amazonia: a prehistoric green revolution or a flood risk mitigation strategy?, J. Archaeol. Sci., 38, 502-512, 2011.

Maldonado, C. and Beck, S. G.: Comunidades sucesionales a orillas del Río Mamoré, in: Diversidad Biológica en la llanura de inundación del Río Mamoré, edited by: Pouilly, M., Beck, S. G., Moraes M. R., and Ibañez, C., Fundación Simon I. Patiño, Santa Cruz de la Sierra, Bolivia, 2004.

Montgomery, D. R. and Abbe, T. B.: Influence of logjam-formed hard points on the formation of valley-bottom landforms in an old-growth forest valley, Queets River, Washington, USA, Quaternary Res., 65, 147-155, 2006.

Neiff, J. J.: Bosques fluviales de la cuenca del Paraná, in: Ecología y manejo de los bosques de Argentina, edited by: Arturi, M., Frangi, J., and Goya, J., Editorial de la Universidad Nacional de La Plata, La Plata, Argentina, 2004. 
Nelson, B. W., Kapos, V., Adams, J. B., Wilson, J. O., and Braun, O. P. G.: Forest Disturbance by Large Blowdowns in the Brazilian Amazon, Ecology, 75, 853-858, 1994.

Pan, Y., Birdsey, R. A., Fang, J., Houghton, R., Kauppi, P. E., Kurz, W. A., Phillips, O. L., Shvidenko, A., Lewis, S. L., Canadell, J. G., Ciais, P., Jackson, R. B., Pacala, S. W., McGuire, A. D., Piao, S., Rautiainen, A., Sitch, S., and Hayes, D.: A Large and Persistent Carbon Sink in the World's Forests, Science, 333, 988993, 2011.

Paneque-Gálvez, J., Mas, J.-F., Guèze, M., Luz, A. C., Macía, M. J., Orta-Martínez, M., Pino, J., and Reyes-García, V.: Land tenure and forest cover change. The case of southwestern Beni, Bolivian Amazon, 1986-2009, Appl. Geogr., 43, 113-126, 2013.

Phillips, O. L., Baker, T. R., Arroyo, L., Higuchi, N., Killeen, T. J., Laurance, W. F., Lewis, S. L., Lloyd, J., Malhi, Y., Monteagudo, A., Neill, D. A., Vargas, P. N., Silva, J. N. M., Terborgh, J., Martínez, R. V., Alexiades, M., Almeida, S., Brown, S., Chave, J., Comiskey, J. A., Czimczik, C. I., Di Fiore, A., Erwin, T., Kuebler, C., Laurance, S. G., Nascimento, H. E. M., Olivier, J., Palacios, W., Patiño, S., Pitman, N. C. A., Quesada, C. A., Saldias, M., Lezama, A. T., and Vinceti, B.: Pattern and process in Amazon tree turnover, 1976-2001, Philos. T. R. Soc. B, 359, 381-407, 2004.

Plotzki, A., May, J. H., Preusser, F., and Veit, H.: Geomorphological and sedimentary evidence for late Pleistocene to Holocene hydrological change along the Río Mamoré, Bolivian Amazon, J. S. Am. Earth Sci., 47, 230-242, 2013.

Rodrigues, L., Lombardo, U., Fehr, S., Preusser, F., and Veit, H.: Pre-Columbian agriculture in the Bolivian Lowlands: Construction history and management of raised fields in Bermeo, Catena, 132, 126-138, 2015.

Rodrigues, L., Lombardo, U., Trauerstein, M., Huber, P., Mohr, S., and Veit, H.: An insight into pre-Columbian raised fields: the case of San Borja, Bolivian lowlands, SOIL, 2, 367-389, https://doi.org/10.5194/soil-2-367-2016, 2016.

Ruiz-Villanueva, V., Piégay, H., Gurnell, A. M., Marston, R. A., and Stoffel, M.: Recent advances quantifying the large wood dynamics in river basins: New methods and remaining challenges, Rev. Geophys., 54, 611-652, 2016.
Salo, J., Kalliola, R., Hakkinen, I., Makinen, Y., Niemela, P., Puhakka, M., and Coley, P. D.: River dynamics and the diversity of Amazon lowland forest, Nature, 322, 254-258, 1986.

Sear, D. A., Millington, C. E., Kitts, D. R., and Jeffries, R.: Logjam controls on channel:floodplain interactions in wooded catchments and their role in the formation of multi-channel patterns, Geomorphology, 116, 305-319, 2010.

Snook, L. K.: Catastrophic disturbance, logging and the ecology of mahogany (Swietenia macrophylla King): grounds for listing a major tropical timber species in CITES, Bot. J. Linn. Soc., 122, 35-46, 1996.

Triska, F.: Role of wood debris in modifying channel geomorphology and riparian areas of a large lowland river under pristine conditions: a historical case study, Verhandlung Internationale Vereinigung Limnologie, 22, 1876-1892, 1984.

Turner, M. G., Baker, W. L., Peterson, C. J., and Peet, R. K.: Factors Influencing Succession: Lessons from Large, Infrequent Natural Disturbances, Ecosystems, 1, 511-523, 1998.

USGS: Landsat image archives, available at: https://landsatlook. usgs.gov/viewer.html, last access: 10 July 2017.

White, P. S. and Jentsch, A.: The Search for Generality in Studies of Disturbance and Ecosystem Dynamics, in: Progress in Botany: Genetics Physiology Systematics Ecology, edited by: Esser, K., Lüttge, U., Kadereit, J. W., and Beyschlag, W., Springer Berlin Heidelberg, Berlin, Heidelberg, 2001.

Wohl, E.: Floodplains and wood, Earth-Sci. Rev., 123, 194-212, 2013.

Wohl, E.: A legacy of absence, Prog. Phys. Geog., 38, 637-663, 2014.

Wohl, E.: Bridging the gaps: An overview of wood across time and space in diverse rivers, Geomorphology, 279, 3-26, 2017.

Wohl, E. and Beckman, N. D.: Leaky rivers: Implications of the loss of longitudinal fluvial disconnectivity in headwater streams, Geomorphology, 205, 27-35, 2014.

Wohl, E., Bolton, S., Cadol, D., Comiti, F., Goode, J. R., and Mao, L.: A two end-member model of wood dynamics in headwater neotropical rivers, J. Hydrol., 462-463, 67-76, 2012. 